\title{
REVIEW
}

\section{Congenital Thyrotropin Deficiency -From Discovery to Molecular Biology, Postgenome and Preventive Medicine-}

\author{
KIYOSHI MIYAI \\ Osaka University (Professor Emeritus), Osaka, Japan \\ Key words: TSH deficiency, Glycoprotein hormone deficiency, CXGXC motif, Central congenital hypothyroidism, Neonatal \\ screening
}

(Endocrine Journal 54: 191-203, 2007)

IT is well known that the human glycoprotein hormone family is comprised of four members: thyrotropin (TSH) and gonadotropin ( $\mathrm{Gn})$, which includes follicle stimulating hormone (FSH), luteinizing hormone (LH) and chorionic gonadotropin (CG) [1, 2]. As shown in Fig. 1, synthesis and secretion of TSH, FSH and LH from the pituitary gland are regulated by the hypothalamic releasing hormones, thyrotropin releasing hormone (TRH) and Gn releasing hormone $(\mathrm{GnRH})$ (luteinizing hormone releasing hormone (LHRH)) as well as by the negative feedback mechanism involving the peripheral hormones, thyroid hormones and sex steroid hormones. The CG synthesized in the placenta is functionally most like LH and essential for the maintenance of pregnancy.

The glycoprotein hormones are composed of two non-covalently linked $\alpha$ - and $\beta$-subunits (chains) as a heterodimer. The amino acid sequence of $\alpha$ (common $\alpha$ ) subunits are identical in all glycoprotein hormones, while those of $\beta$ subunits are homologous to each other yet each is unique and these differences confer the specific biological activities. Complex carbohydrate side chains are attached to the $\alpha$ - and $\beta$-subunits. Isolation, cloning and sequence analysis of the DNAs for glycoprotein hormones and their transcription factors have been performed extensively.

Congenital glycoprotein hormone deficiency is classified into three types: isolated deficiency with lack of a single hormone, combined (multiple) deficiency (partial hypopituitarism) associated with lack of other pituitary hormones, and panhypopituitarism. On the

Correspondence to: Kiyoshi MIYAI, Osaka University (Professor Emeritus), Osaka, Japan other hand, hypothyroidism and hypogonadism are classified into four types according to the site of impairment in the hypothalamic- pituitary- thyroidal and gonadal axis (Fig. 1). In the case of hypothyroidism, three types are known: central including hypothalamic (tertiary) and pituitary (secondary), primary (impairment of the thyroid gland itself) and peripheral (resistance to thyroid hormone).

In 1971, the first case of congenital glycoprotein hormone deficiency was reported by Miyai et al. [3] as a familial isolated TSH deficiency with congenital hypothyroidism (cretinism). The case was well documented by sophisticated clinical laboratory tests such as immunoassay and provocation tests. About two decades later, introduction of molecular biology techniques paved the way for the gene analyses of the patient. We performed molecular cloning of hTSH $\beta$ subunit gene $[4,5]$ and demonstrated that a single base substitution in the CAGYC region of the TSH $\beta$ subunit was responsible for this disorder [6,7]. Based on our subsequent studies on wild and mutant types of glycoprotein hormones with site directed mutagenesis of the CAGYC region in the $\beta$-subunits and CMGCC region in the $\alpha$-subunit $[6,8-10]$, we hypothesized that the CXGXC motif plays an important role in the biosynthesis of glycoprotein hormones [11]. Recently, postgenome medicine has attracted special interest and we studied the three dimensional structure of the CXGXC motif of wild glycoprotein hormones as well as mutant types that simulate the isolated TSH deficiency [12]. Furthermore, in 1992, we cloned a transcription factor, human Pit-1 (PIT1) gene [13], and discovered the first case of combined deficiency of $\mathrm{TSH}$, growth hormone $(\mathrm{GH})$ and prolactin (PRL), 
caused by a mutation in the PIT1 gene, as a typical model of so-called transcription factor disease [14]. We also attempted to develop the neonatal screening method for congenital hypothyroidism of central as well as primary types [15].

The main purpose of this review is to describe and discuss our experiences in the discovery, clinical study and genetic analysis of the responsible genes and in neonatal screening for congenital TSH deficiency. We also describe our studies on the CXGXC motif of glycoprotein hormones and hypothetical disorders related to glycoprotein hormones.

\section{Congenital TSH deficiency}

1. Congenital isolated TSH deficiency caused by mutation in the TSH $\beta$-subunit gene ([i] in Fig. 1)

\subsection{Discovery of the first case}

A half century ago, suspected cases of congenital
TSH deficiency had been reported but diagnosis of the disease was insufficiently documented before the availability of the TSH immunoassay and provocation test with TRH (TRH test). For instance, Turner and Takamura [16] reported a case of suspected congenital isolated TSH deficiency but our reevaluation of the same patient demonstrated that the case had primary hypothyroidism [17]. In 1971, we found the first well documented case of congenital isolated TSH deficiency [3]. The discovery was made not by chance but by a strategy based on a logical hypothesis according to analogy with known clinical entities. At that time, primary and peripheral types of congenital hypothyroidism as well as primary and central types of acquired hypothyroidism were known, but there had not been any reported congenital cases of the central type. On the other hand, isolated pituitary hormone deficiency other than congenital isolated TSH deficiency had been reported. Clinical findings of the hypothetical congenital isolated TSH deficiency would be expected as follows: 1) the patient would demonstrate clinical

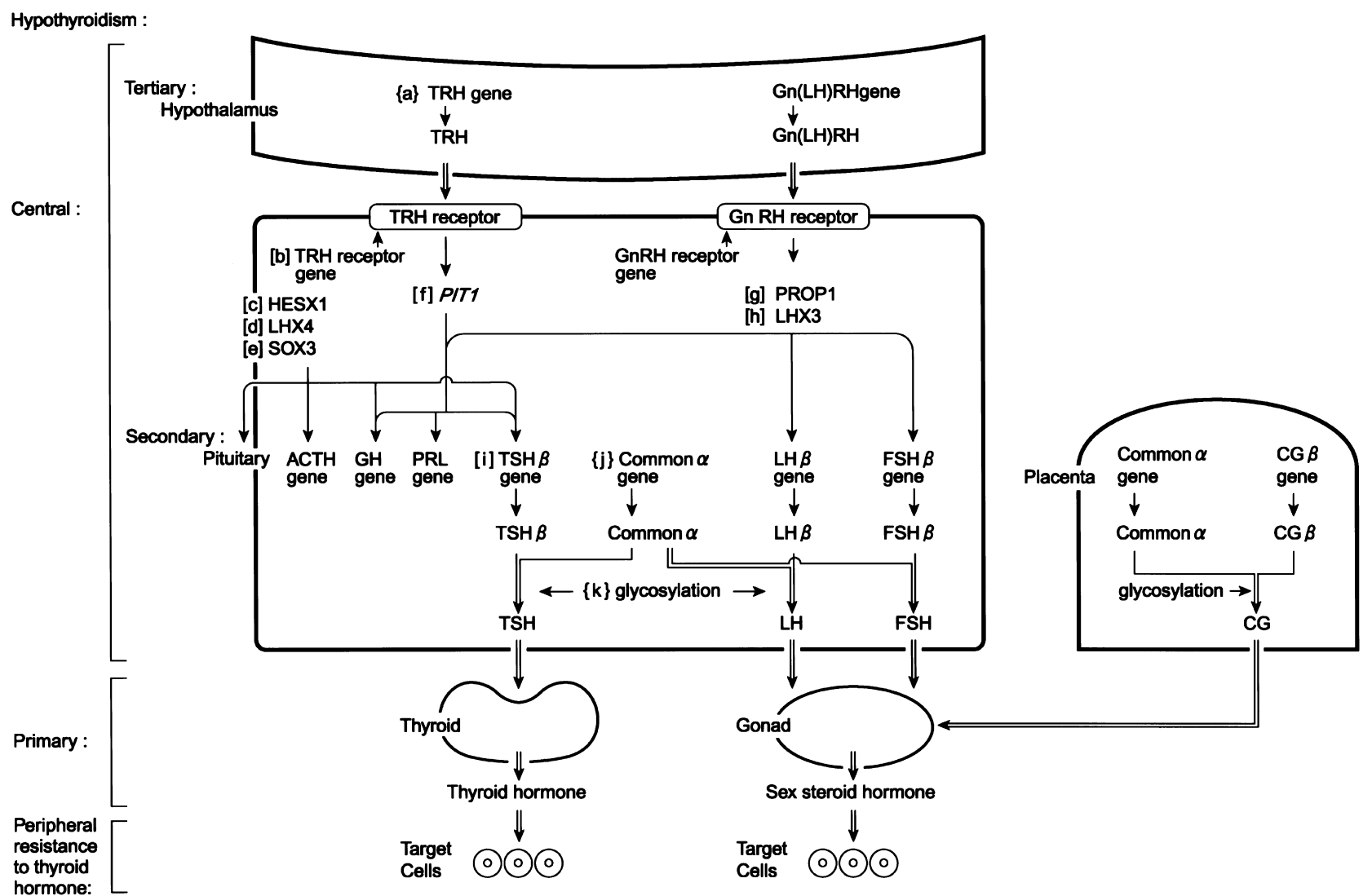

Fig. 1. Schematic view of the hypothalamic pituitary thyroidal- and -gonadal axis. Possible sites for causing congenital TSH deficiency are indicated by [ ] (already reported) and \{\} (hypothetical disorders). 
manifestations of nongoitrous cretinism, and 2) assuming that the disorder is inherited, familial occurrence would be expected. We therefore focused our approach on searching for nongoitrous cretinism appearing in siblings and/or offspring of a consanguineous marriage, and finally identified the first case in Japan. The proposita were 2 sisters with congenital TSH deficiency and their parents' marriage was consanguineous.

\subsection{Clinical features and laboratory findings}

Severe cases such as those we reported showed typical signs and symptoms of nongoitrous cretinism. Thyroidal radioactive iodine uptake was low but substantially increased after administration of TSH. Serum concentrations of (free) thyroxine $\left(\mathrm{T}_{4}\right)$ and 3,5,3'triiodothyronine $\left(\mathrm{T}_{3}\right)$ were low and those of TSH were consistently undetectable, which did not increase after administration of TRH in either hypothyroid or euthyroid states. The detectable free common $\alpha$ subunit in serum was increased by TRH and was decreased by thyroid hormone administration, suggesting that the common $\alpha$-subunit gene is intact [18]. Plasma TRH was detectable by radioimmunoassay [19], although the technique has not yet to be established. That the TSH deficiency was isolated was confirmed by provocation tests of other pituitary hormones; that is, significant increase of serum PRL to TRH administration, of FSH and LH to GnRH, of GH to growth hormone releasing hormone (GRH) and of adrenocorticotropic hormone (ACTH) to corticotropin releasing hormone $(\mathrm{CRH})$ or insulin induced hypoglycemia were observed $[3,19]$. In the first cases, unexpected abnormal increases in serum GH were observed after intravenous injection of TRH, GnRH and CRH, while serum GH level did not change after saline injection as a control experiment $[19,20]$. There were no confirmatory studies on the peculiar phenomenon and the mechanism remains unknown. The parents of the first cases were phenotypically normal with normal responses to the provocation tests.

\subsection{Genetic analysis of TSH $\beta$-subunit gene}

In 1985 we first performed molecular cloning of hTSH $\beta$ subunit gene $[4,5]$. Later on we analyzed the TSH $\beta$-subunit gene in the first case of congenital isolated TSH deficiency and found a single base substitution from guanine $(G)$ to adenine $(A)$ at position 85 which altered $G G A$ encoding glycine (Gly) (G) to
$A G A$ encoding arginine (Arg) (R) at the 29th codon ([G29R]) [6, 7, 21]. The missense mutation was found to be homozygous in two patients in siblings and heterozygous in their parents whose marriage was consanguineous indicating that the mutation was responsible for the disease, and that the inheritance was recessive. The same mutation was demonstrated in 6 affected members in 5 Japanese families so far examined [6, 7, 21, 22]. Although mutual blood relationships among the families were not clear from the family history, all families originated from a small area in the western part of Shikoku Island in Japan and an identical polymorphism in intron 2 was associated with the mutation in 3 patients in different families. These findings suggest that the mutant gene originated from a common ancestor.

To date, different mutations have been reported for the TSH $\beta$-subunit gene in congenital isolated TSH deficiency, as shown in Table $1[6,7,21-29]$. The mutations were homozygous or compound heterozygous. For instance, in the case reported by Karges et al. [30], mutations were found at codon 49 in one allele and 105 in the other allele in which cytocine $(C)$ to thymine $(T)$ transition at codon 49 resulted in alteration of glutamine (Gln) (Q) to stop (termination) codon (X) and deletion of one base pair $T$ at codon 105 resulted in alteration of cysteine (Cys) (C) to valine (Val) (V) followed by frameshift (fs) and stop codon (X) at 114. These were described as [Q49X]/ [C105delT (fs 114X)]. There were some differences in their clinical features. For instance, in patients with a mutation [Q49X], the circulating TSH was found to be immunologically active (detectable by immunoassay) but biologically inactive (recombinant TSH harboring this mutation had no biological activity that could be determined by bioassay) [25].

\section{Congenital TSH deficiency associated with com- bined pituitary hormone deficiency caused by mutation in the transcription factor gene}

\subsection{Discovery of the first case of PIT1 deficiency ([f] in Fig. 1)}

In 1980, in the course of searching for congenital isolated TSH deficiency, we encountered a case report describing congenital TSH deficiency and we contacted both the author and the patient. Reevaluation of the patient demonstrated that the disorder was not isolated TSH deficiency but combined deficiency of 
Table 1. Reported mutations in genes related to congenital TSH deficiency. Data were obtained from figures [38, 42, $46]$ and original articles [6, 7, 14, 21-29, 34-52, 58]. Refer to Fig. 1 [ ] and abbreviations.

\begin{tabular}{|c|c|}
\hline TRH receptor $[\mathrm{b}]$ & $\begin{array}{l}\text { PROP1 } \\
\text { Pronhet of Pit-1) }[\mathrm{g}]\end{array}$ \\
\hline $\begin{array}{l}\text {-SIT } 115116117 \mathrm{del}^{(38)} \\
\cdot \text { A118T }\end{array}$ & $\begin{array}{l}(\text { Prophet of Pit-1) }[\mathrm{g}] \\
\cdot \mathrm{S} 38 \text { del } 13 \mathrm{bp}\end{array}$ \\
\hline TSH- $\beta$ subunit $[\mathrm{i}]$ & $\left.(112-114 \operatorname{del} b p)^{42}\right)$ \\
\hline$\cdot \mathrm{E}_{\left.12 \mathrm{X}^{23}\right)}$ & - G50 del GA \\
\hline$\cdot \mathrm{G}_{2} 9 \mathrm{R}^{6,7,21,22)}$ & $(149 \operatorname{del} G A)^{40)}$ \\
\hline$\cdot \mathrm{Q}_{49 \mathrm{X}^{25,26)}}$ & $\cdot \mathrm{R} 53 \operatorname{del} A$ \\
\hline - F57 del $T^{29)}$ & $(147 \mathrm{del} A)^{42)}$ \\
\hline$(266 \operatorname{del~T})$ & $\cdot \mathrm{R}_{1} \mathrm{C}^{41}$ \\
\hline$\cdot\left(\mathrm{C} 85 \mathrm{R}^{27)}\right.$ & $\cdot \mathrm{R} 7 \mathrm{H}^{41)}$ \\
\hline$\cdot \mathrm{C} 105 \mathrm{del} T^{24)}$ & $\cdot \mathrm{R}_{3} 3 \mathrm{C}^{42)}$ \\
\hline$(410 \mathrm{del} T)$ & $\cdot \mathrm{R}_{3} 3 \mathrm{H}^{42)}$ \\
\hline$\cdot \operatorname{IVS} 2(+5) G>A^{28)}$ & $\cdot \mathrm{Q}^{2} 3 \mathrm{X}^{42)}$ \\
\hline PIT1 (Human Pit-1) & $\cdot \mathrm{F}_{88 \mathrm{~S}^{42}}$ \\
\hline (GHF1) (POU1F1) [f] & $\cdot \mathrm{R}_{\left.99 \mathrm{X}^{42}\right)}$ \\
\hline$\cdot \mathrm{Q} 4 \mathrm{X}^{38)}$ & $\cdot \mathrm{R}_{99 Q^{42)}}$ \\
\hline$\cdot \mathrm{P} 14 \mathrm{~L}^{38)}$ & - $\mathrm{S} 101 \mathrm{del} A G$ \\
\hline$\cdot \mathrm{P} 24 \mathrm{~L}^{36,38)}$ & $(301 \mathrm{del} A G)^{39,42)}$ \\
\hline$\cdot F 135 C^{38)}$ & $\cdot \operatorname{IVS} 2(-2) A>T^{42)}$ \\
\hline$\cdot R 143 Q^{36,38)}$ & $\cdot F 117 \mathrm{I}^{39,42)}$ \\
\hline$\cdot \mathrm{R} 143 \mathrm{~L}^{37)}$ & $\cdot \mathrm{R} 120 \mathrm{C}^{39,42)}$ \\
\hline$\cdot \mathrm{R}_{\left.145 \mathrm{X}^{38}\right)}$ & - S156 ins $T$ \\
\hline$\left.\cdot \mathrm{A} 158 \mathrm{P}^{38}\right)$ & $(467 \text { ins } T)^{44)}$ \\
\hline$\cdot \mathrm{Q} 167 \mathrm{X}^{38)}$ & $\cdot \mathrm{W} 194 \mathrm{X}^{43)}$ \\
\hline$\cdot \mathrm{R} 172 \mathrm{Q}^{38)}$ & HESX1 [c] \\
\hline$\cdot \mathrm{R} 172 \mathrm{X}^{14,38)}$ & $\cdot \mathrm{Q}^{4} \mathrm{H}^{46)}$ \\
\hline$\cdot E 174 G^{38)}$ & $\cdot \mathrm{I}^{\left.26 \mathrm{~T}^{47}\right)}$ \\
\hline$\cdot \mathrm{S} 179 \mathrm{R}^{38)}$ & $\cdot \mathrm{R}_{53} \mathrm{C}^{45)}$ \\
\hline$\cdot \mathrm{W} 193 \mathrm{R}^{38)}$ & . 306307 ins $A G^{47)}$ \\
\hline$\cdot$ L194Q 37$)$ & $\cdot \mathrm{R} 160 \mathrm{C}^{46)}$ \\
\hline$\cdot \mathrm{K} 216 \mathrm{E}^{38)}$ & $\cdot \mathrm{S} 170 \mathrm{~L}^{46)}$ \\
\hline$\cdot \mathrm{E} 230 \mathrm{~K}^{38)}$ & $\cdot \mathrm{N} 178 \mathrm{del} G^{48)}$ \\
\hline$\cdot F 233 \mathrm{~L}^{38)}$ & $\cdot \mathrm{T} 181 \mathrm{~A}^{46)}$ \\
\hline$\cdot \mathrm{P} 239 \mathrm{~S}^{38)}$ & LHX3 [h] \\
\hline$\cdot$ E249 del $A$ & $\cdot \mathrm{Y} 116 \mathrm{C}^{49)}$ \\
\hline$(747 \mathrm{del} A)^{38)}$ & $\cdot 159 \mathrm{del} T^{50)}$ \\
\hline$\cdot \mathrm{E}_{250 \mathrm{X}^{38}}$ & $\cdot \operatorname{del}$ LHX3 $^{49)}$ \\
\hline$\cdot$ V260 ins $A$ & LEX4 [d] \\
\hline$(778 \text { ins } A)^{38)}$ & $\cdot$ IVS4(-1) $G>C^{51)}$ \\
\hline$\cdot \mathrm{R} 265 \mathrm{~W}^{38)}$ & SOX3 [e] \\
\hline$\cdot \mathrm{R}_{2} 21 \mathrm{~W}^{34,38)}$ & - A240 ins $21 b p^{52)}$ \\
\hline$\cdot V 272 X^{38)}$ & \\
\hline$\cdot \operatorname{del} P_{\left.T T 1^{35}\right)}$ & \\
\hline
\end{tabular}

Abbreviations.

Nucleotides, $A$ : adenine; $C$ : cytocine; $G$ : guanine; $T$ : thymine; $b p$ : base pair of nucleotide; number: nucleotide number; IVS: intervening sequence

Amino acids, A, Ala: alanine; C, Cys: cysteine; D, Asp: asparatic acid; E, Glu: glutamic acid; F, Phe: phenylalanine; G, Gly: glycine; H, His: histidine; I, Ile: isoleucine; K, Lys: lysine; L, Leu: leucine; M, Met: methionine; N, Asn: asparagine; P, Pro: proline; Q, Gln: glutamine; R, Arg: arginine; S, Ser: serine; T, Thr: threonine; V, Val: valine; W, Trp: tryptophane; Y, Tyr: tyrosine; number: codon number;

Mutations, del, del: deletion; ins : insertion; >: transition; X: stop (termination) codon

Examples, SIT $115116117 \mathrm{del}$ : serine, isoleucine and threonine at codon 115,116 and 117 are deleted; E12X: glutamic acid at codon 12 changes to stop codon; G29R: glycine at codon 29 changes to arginine; F57 $\mathrm{del} T$ (266 $\mathrm{del} T): 266^{\text {th }}$ nucleotide, thymine is deleted at codon 57 (phenylalanine); IVS2(+5) $G>A$ : guanine to adenine transition at position +5 in the $2^{\text {nd }}$ intervening sequence; V260 ins $A$ (778 ins $A$ ); adenine is inserted at codon 260 (valine) $\left(778^{\text {th }}\right.$ nucleotide)
TSH, GH, and PRL which seemed to be a common pituitary dwarfism associated with other pituitary hormone failure. However, since the patient was one of two affected siblings and the offspring of a consanguineous marriage, we hypothesized that the disorder was caused by a mutation in an unknown gene that controls synthesis and/or secretion of the three hormones. We then took blood samples from the patient and her family with their permission. In 1988, rat Pit-1 (GHF-1) (current nomenclature: POU1F1) was cloned as a transcription factor for GH and PRL [31]. As dwarf mice ( $d w$ and $d f$ ) had apparently similar hormone deficiencies of TSH and GH [32], we started to conduct studies on mouse and human Pit-1 genes as a candidate gene for the disorder. In1990, Li et al. [33] reported that the $d w$ mouse showed disruptions in the Pit-1 gene. In 1992, we cloned the human Pit-1 (PIT1) gene [13]. At that time we were unable to reestablish contact with the patient's family, but we could analyze the PIT1 gene using the stored blood samples [14].

\subsection{Genetic analysis of PIT1, PROP1, HESX1, LHX3 LHX4 and SOX3 genes}

In the first case of combined deficiencies of TSH, $\mathrm{GH}$ and PRL caused by a homozygous nonsense mutation in the PITl gene, one base alteration, a $C$ to $A$ in exon 4 converted the $172^{\text {nd }}$ codon for $A r g$ to a stop codon $(\mathrm{X})([\mathrm{R} 172 \mathrm{X}])$ [14]. To date different mutations in the PIT1 gene have been reported as shown in Table 1 [14, 34-38].

Since then, the mutations of other transcription factor genes in cases of combined pituitary hormone deficiency such as PROP1 (Prophet of Pit 1) (TSH, GH, PRL, Gn deficiency) ([g] in Fig. 1) [39-44], HESX1 (pituitary hypoplasia and septo-optico dysplasia) ([c] in Fig. 1) [45-48], LHX3 (TSH, GH, PRL, Gn deficiency and rigid cervical spine) ([h] in Fig. 1) $[49,50]$, LHX4 (TSH, GH, ACTH deficiency) ([d] in Fig. 1) [51], and SOX3 (panhypopituitarism and infundibular hypoplasia) ([e] in Fig. 1) [52] have been reported as shown in Table 1. These mutations involved homozygosity, heterozygosity (dominant negative mutation/haploinsufficiency) or compound heterozygosity for the genes. The degree of deficiencies of pituitary hormones as well as clinical manifestations in these cases were varied. 


\section{Congenital TSH deficiency due to TRH deficiency and other etiology}

In 1975, Illig et al. [53] reported that circulating TSH determined by immunoassay was elevated in children with hypothalamic hypopituitarism and suggested that TSH in the patients was immunologically active but biologically inactive. Subsequent studies on hypothalamic hypothyroidism demonstrated that serum TSH was detectable by immunoassay but low when determined by cytochemical bioassay with decreased receptor binding activity [54]. In 1981 Spitz et al. [55] reported euthyroid patients with increased serum levels of TSH with high molecular weight and low biological activity but subsequent studies have not appeared.

In 1979 Smail et al. [56] reported a case of congenital mild hypothyroidism with a low level of serum free $\mathrm{T}_{4}$ and detectable immunoreactive $\mathrm{TSH}$, which increased slightly after administration of TRH. Since the patient did not demonstrate any other pituitary hormone deficiency, it was suggested that the hypothyroidism was due to isolated TRH deficiency, and it was demonstrated that serum TRH was undetectable in a similar case even after administration of antithyroid drug [57].

In 1997, Collu et al. [58] reported a case of congenital central hypothyroidism with complete absence of TSH and PRL responses to TRH administration but without other pituitary hormone deficiencies. Genetic analysis of the TRH receptor gene in the patient demonstrated a compound heterozygosity for two mutations [SIT 115, 116, $117 \mathrm{del}] /[\mathrm{A} 118 \mathrm{~T}]$ as shown in Fig. 1 ([b]) and Table 1.

Many cases of congenital TSH deficiency with unknown etiology have been reported and further studies are required.

\section{Neonatal screening for central hypothyroidism}

Since growth and irreversible mental retardation due to congenital hypothyroidism can be prevented by early diagnosis and treatment, neonatal mass screening has been widely performed. Measurement of decreased $\mathrm{T}_{4}$ in dried blood samples on filter paper taken from neonates by radioimmunoassy (RIA) [59] and non-isotopic enzyme immunoassay (EIA) [60] can detect all but peripheral types; however, this test gives false positive results for subjects with $\mathrm{T}_{4}$ binding glob- ulin (TBG) deficiency who do not require treatment. Then we developed RIA [61] and EIA [62] for measuring free $T_{4}$ which was not influenced by TBG deficiency but these $T_{4}$ methods risk overlooking mild cases. Since measurement of elevated TSH is useful for detecting even mild cases of primary type, which are the most common, RIA [63-66] and EIA [67-69] for measuring TSH in dried blood samples have been developed. However, the sensitivity of conventional enzyme linked immunosorbent assay (ELISA) for TSH in currently use is too low to detect decreased TSH in central type. Therefore measurements of both TSH and free $\mathrm{T}_{4}$ (or $\mathrm{T}_{4}$ plus TBG) have been used for screening central type [70]. Recently we developed a highly sensitive bioluminescence ELISA for TSH, which is expected to be useful for detecting both primary and central types with a single assay [15]. The incidence of the primary type has been estimated to be as high as 1:3,000 [71], whereas that of central type was estimated as low as $1: 20,000$ [70]. However, since case reports of central type have increased and the incidence seems to be higher in some areas such as Shikoku Island in Japan as described above, neonatal mass screening for central type of congenital hypothyroidism should be promoted in the future.

\section{Significance of the CXGXC motif}

\section{CXGXC motif in patients with congenital glycopro- tein hormone deficiency}

As indicated above, 6 Japanese patients with congenital isolated TSH deficiency caused by a missense mutation in the TSH $\beta$-subunit gene had a Gly $(\mathrm{G})$ to $\operatorname{Arg}(\mathrm{R})$ transition $([\mathrm{G} 29 \mathrm{R}])$ in the CAGYC region $[6,7,21,22]$. The amino acid sequence of this region is composed of Cys (C)-alanine (Ala) (A)-Gly (G)-tyrosine (Tyr) (Y)-Cys (C), and described as $\mathrm{C}_{1} \mathrm{~A}_{2} \mathrm{G}_{3} \mathrm{Y}_{4} \mathrm{C}_{5}$ in normal subjects and $\mathrm{C}_{1} \mathrm{~A}_{2} \mathrm{R}_{3} \mathrm{Y}_{4} \mathrm{C}_{5}$ in the patients. Recently Valdes-Socin et al. [72] reported a case of hypogonadism due to isolated $\mathrm{LH}$ deficiency caused by a missense mutation in the $\mathrm{LH}$ $\beta$-subunit gene which changed Gly (G) to aspartic acid (Asp) (D) ([G36D]) in the same CAGYC region described as $\mathrm{C}_{1} \mathrm{~A}_{2} \mathrm{D}_{3} \mathrm{Y}_{4} \mathrm{C}_{5}$ (Table 2). 
Table 2. Relationship between amino acid sequence of CXGXC motif and the immunological and/or biological activities of wild and mutant types of glycoprotein hormones (boldface: active, (italic): inactive). The sequences were obtained from Database of the National Center for Biotechnology Information [73], the Table [10] and original articles [6-10,21, 22, 72, 74]. Abbreviations of amino acids: see Table 1 .

\begin{tabular}{|c|c|c|c|c|c|c|c|c|c|c|}
\hline & \multicolumn{5}{|c|}{ Common $\alpha$-subunit } & \multicolumn{5}{|c|}{$\beta$-subunit } \\
\hline \multicolumn{11}{|l|}{ Wild type } \\
\hline human (h) & C & M & $\mathbf{G}$ & C & $\mathbf{C}$ & C & A & G & $\mathbf{Y}$ & C \\
\hline \multirow[t]{14}{*}{ other species } & - & - & - & - & - & - & - & - & - & - \\
\hline & - & $\mathbf{A}$ & - & - & - & - & - & - & $\mathbf{F}$ & - \\
\hline & - & $\mathbf{K}$ & - & - & - & - & - & - & $\mathbf{H}$ & - \\
\hline & - & $\mathbf{S}$ & - & - & $-^{74)}$ & - & - & - & $\mathbf{L}$ & - \\
\hline & - & $\mathbf{T}$ & - & - & - & - & $\mathbf{E}$ & - & - & - \\
\hline & - & $\mathbf{V}$ & - & - & - & - & $\mathbf{E}$ & - & $\mathbf{L}$ & - \\
\hline & - & $\mathbf{V}$ & - & $\mathbf{H}$ & - & - & $\mathbf{E}$ & - & $\mathbf{Q}$ & - \\
\hline & & & & & & - & G & - & - & - \\
\hline & & & & & & - & $\mathbf{M}$ & - & - & - \\
\hline & & & & & & - & $\mathbf{S}$ & - & - & - \\
\hline & & & & & & - & $\mathbf{S}$ & - & $\mathbf{H}$ & - \\
\hline & & & & & & - & $\mathbf{T}$ & - & - & - \\
\hline & & & & & & - & $\mathbf{T}$ & - & $\mathbf{L}$ & - \\
\hline & & & & & & - & $\mathbf{W}$ & - & $\mathbf{R}$ & - \\
\hline \multicolumn{11}{|c|}{ Site directed mutagenesis } \\
\hline control & $\mathbf{C}$ & M & $\mathbf{G}$ & $\mathrm{C}$ & C & $\mathbf{C}$ & $\mathbf{A}$ & $\mathbf{G}$ & $\mathbf{Y}$ & C \\
\hline mutagenesis & $(Y)$ & - & - & - & -9,10) & - & D & - & - & -8) \\
\hline \multirow{4}{*}{ (hTSH and/or hCG) } & - & $\mathbf{R}$ & - & - & $-^{10)}$ & - & - & (D) & - & —8) \\
\hline & - & - & $(A)$ & - & -9,10) & - & - & $(R)$ & - & - $^{6,8)}$ \\
\hline & - & - & (D) & - & —, & & & & & \\
\hline & - & - & $(R)$ & - & —, & & & & & \\
\hline \multicolumn{11}{|c|}{ Diseases } \\
\hline \multirow{2}{*}{\multicolumn{2}{|c|}{$\begin{array}{l}\text { Isolated LH deficiency }{ }^{72)} \\
\text { Isolated TSH deficiency } y^{6,721,22)}\end{array}$}} & & & & & - & - & (D) & - & - \\
\hline & & & & & & - & - & $(R)$ & - & - \\
\hline
\end{tabular}

\section{2. $C X G X C$ motif in wild type glycoprotein hormones}

As shown in Table 2, the same $\mathrm{C}_{1} \mathrm{~A}_{2} \mathrm{G}_{3} \mathrm{Y}_{4} \mathrm{C}_{5}$ motif is found in $\beta$-subunits of all glycoprotein hormones in humans as well as in certain species. The amino acids, Ala, glutamic acid (Glu) (E), Gly, methionine (Met) (M), serine (Ser) (S), threonine (Thr) (T), tryptophan (Trp) (W) at site $\mathrm{X}_{2}$ and phenylalanine (Phe) (F), histidine (His) (H), leucine (Leu) (L), Gln, Arg, Tyr at $\mathrm{X}_{4}$ have been identified and examined to date $[10,73]$. Therefore at least the $\mathrm{C}_{1} \mathrm{X}_{2} \mathrm{G}_{3} \mathrm{X}_{4} \mathrm{C}_{5}$ motif is highly conserved among species, where amino acids at $\mathrm{X}$ are variable.

On the other hand, a similar amino acid sequence Cys (C)-Met(M)-Gly (G)-Cys (C)-Cys (C) $\left(\mathrm{C}_{1} \mathrm{M}_{2} \mathrm{G}_{3} \mathrm{C}_{4} \mathrm{C}_{5}\right)$ is found in the human common $\alpha$ subunit. Again, the motif is highly conserved among species and described as $\mathrm{C}_{1} \mathrm{X}_{2} \mathrm{G}_{3} \mathrm{X}_{4} \mathrm{C}_{5}$, where the amino acids, Ala, lysine (Lys) (K), Met, Ser, Thr, Val at site $\mathrm{X}_{2}$ and Cys, His at site $\mathrm{X}_{4}$ have been identified and examined to dates $[10,73,74]$.

\section{Site directed mutagenesis in the CMGCC and $C A G Y C$ regions of the $\alpha$ and $\beta$-subunits of glycopro- tein hormones}

We studied the effect of site directed mutagenesis in the $\mathrm{C}_{1} \mathrm{M}_{2} \mathrm{G}_{3} \mathrm{C}_{4} \mathrm{C}_{5}[9,10]$ and $\mathrm{C}_{1} \mathrm{~A}_{2} \mathrm{G}_{3} \mathrm{Y}_{4} \mathrm{C}_{5}[6,8]$ regions of the human TSH and/or CG in terms of the immunological and/or biological activities. As shown in Table 2, there were no detectable hormone activities in mutant TSH and CG in which the middle Gly $\left(\mathrm{G}_{3}\right)$ in the $\mathrm{C}_{1} \mathrm{M}_{2} \mathrm{G}_{3} \mathrm{C}_{4} \mathrm{C}_{5}$ region of the $\alpha$-subunit were altered to Ala, Asp and Arg $\left(\mathrm{C}_{1} \mathrm{M}_{2} \mathrm{~A}_{3} \mathrm{C}_{4} \mathrm{C}_{5}, \mathrm{C}_{1} \mathrm{M}_{2} \mathrm{D}_{3} \mathrm{C}_{4} \mathrm{C}_{5}\right.$ and $\mathrm{C}_{1} \mathrm{M}_{2} \mathrm{R}_{3} \mathrm{C}_{4} \mathrm{C}_{5}$ ), and Cys at site $\mathrm{C}_{1}$ was altered to Tyr $\left(\mathrm{Y}_{1} \mathrm{M}_{2} \mathrm{G}_{3} \mathrm{C}_{4} \mathrm{C}_{5}\right)$. Similarly, the mutant TSH and/or CG lost hormone activity when Gly $\left(\mathrm{G}_{3}\right)$ in the $\mathrm{C}_{1} \mathrm{~A}_{2} \mathrm{G}_{3} \mathrm{Y}_{4} \mathrm{C}_{5}$ region of the $\beta$-subunit was altered to 
Asp (D) and $\operatorname{Arg}(\mathrm{R})$ as patients with isolated LH deficiency $\left(\mathrm{C}_{1} \mathrm{~A}_{2} \mathrm{D}_{3} \mathrm{Y}_{4} \mathrm{C}_{5}\right)$ and TSH deficiency $\left(\mathrm{C}_{1} \mathrm{~A}_{2} \mathrm{R}_{3} \mathrm{Y}_{4} \mathrm{C}_{5}\right)$, respectively. However, hormone activity was retained when $\mathrm{X}_{2}$ was changed to Arg as $\mathrm{C}_{1} \mathrm{R}_{2} \mathrm{G}_{3} \mathrm{C}_{4} \mathrm{C}_{5}$ in the TSH $\alpha$-subunit and to Asp as $\mathrm{C}_{1} \mathrm{D}_{2} \mathrm{G}_{3} \mathrm{Y}_{4} \mathrm{C}_{5}$ in the $\mathrm{CG} \beta$-subunit.

Based on findings obtained from the wild type and mutant type glycoprotein hormones in patients as well as site directed mutagenesis experiments, we hypothesized that the CXGXC motif in both $\alpha$ and $\beta$-subunits play important roles in the biosynthesis of glycoprotein hormones [11, 12].

\section{Three dimensional structure of the CXGXC motif}

An early study on the secondary structure of the $\mathrm{C}_{1} \mathrm{M}_{2} \mathrm{G}_{3} \mathrm{C}_{4} \mathrm{C}_{5}$ and $\mathrm{C}_{1} \mathrm{~A}_{2} \mathrm{G}_{3} \mathrm{Y}_{4} \mathrm{C}_{5}$ regions by the ChouFasman prediction suggested that these regions have type II turns in which Gly $\left(\mathrm{G}_{3}\right)$ is a candidate for the structure [11]. In 1994, however, Lapthorn et al. [75] and Wu et al. [76] reported the three dimensional crystal structure of hCG indicating that the regions do not have turn structures but $\beta$-strands. The study demonstrated that a common disulfide bridge (bond) $\left(\mathrm{C}_{\mathrm{s}}\right)$ and a unique disulfide bridge (cystine knot $\left(\mathrm{C}_{\mathrm{k}}\right)$ ) are located in the regions $\left(\mathrm{C}_{\mathrm{k} 1} \mathrm{M}_{2} \mathrm{G}_{3} \mathrm{C}_{\mathrm{s} 4} \mathrm{C}_{\mathrm{k} 5}\right.$ and $\left.\mathrm{C}_{\mathrm{k} 1} \mathrm{~A}_{2} \mathrm{G}_{3} \mathrm{Y}_{4} \mathrm{C}_{\mathrm{k} 5}\right)$ suggesting that two disulfide bridges at both ends $\left(\mathrm{C}_{\mathrm{k} 1}\right.$ and $\left.\mathrm{C}_{\mathrm{k} 5}\right)$ are essential in the regions.

To assess the importance of Gly $\left(\mathrm{G}_{3}\right)$ in the regions, we analyzed the three dimensional structure of the regions by the conformational energy calculation using a computational procedure [12]. We performed the main chain conformational calculation for our models of five residues in which the positions of Cys residues at both ends $\left(\mathrm{C}_{\mathrm{k} 1}\right.$ and $\left.\mathrm{C}_{\mathrm{k} 5}\right)$ were fixed in space, and bond lengths and bond angles of the peptides were maintained at standard values by the loop closure algorithm. Calculating all the combinations of 8 dihedral angles $(\Phi$ and $\Psi$ ) corresponds to exploring all the main chain conformations and we selected only the conformations where the peptide chain atoms do not collide with surrounding atoms.

Fig. 2 (a) illustrates the stick model of the peptide chain of the $\mathrm{C}_{1} \mathrm{M}_{2} \mathrm{G}_{3} \mathrm{C}_{4} \mathrm{C}_{5}$ motif in the $\alpha$-chain showing a stable structure. Ramachandran plot analysis which shows the allowed area of the dihedral angles $(\Phi$ and $\Psi$ ) also demonstrated that only Gly was allowed at site $\mathrm{X}_{3}\left(\mathrm{G}_{3}\right)$. In the stick model of the $\mathrm{C}_{1} \mathrm{~A}_{2} \mathrm{G}_{3} \mathrm{Y}_{4} \mathrm{C}_{5}$ motif in the $\beta$-chain, a small diversity was (a) $\operatorname{CMGCC}(\alpha$-chain)

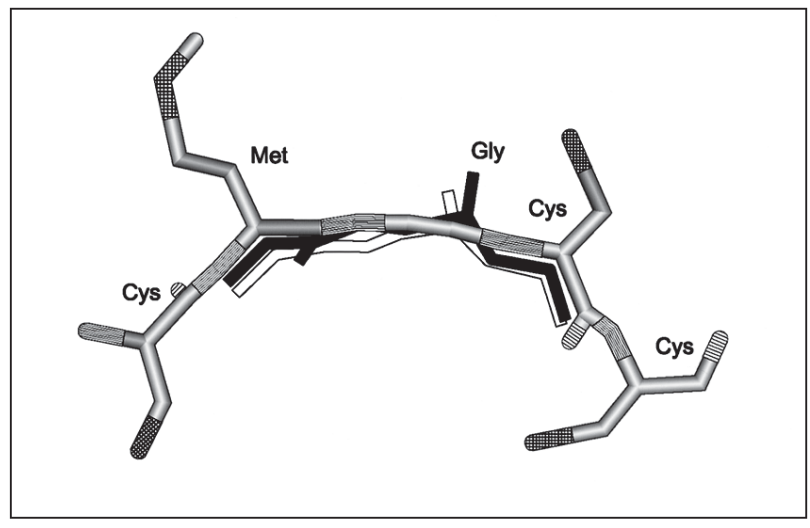

(b) $\operatorname{CAGYC(~} \beta$-chain)

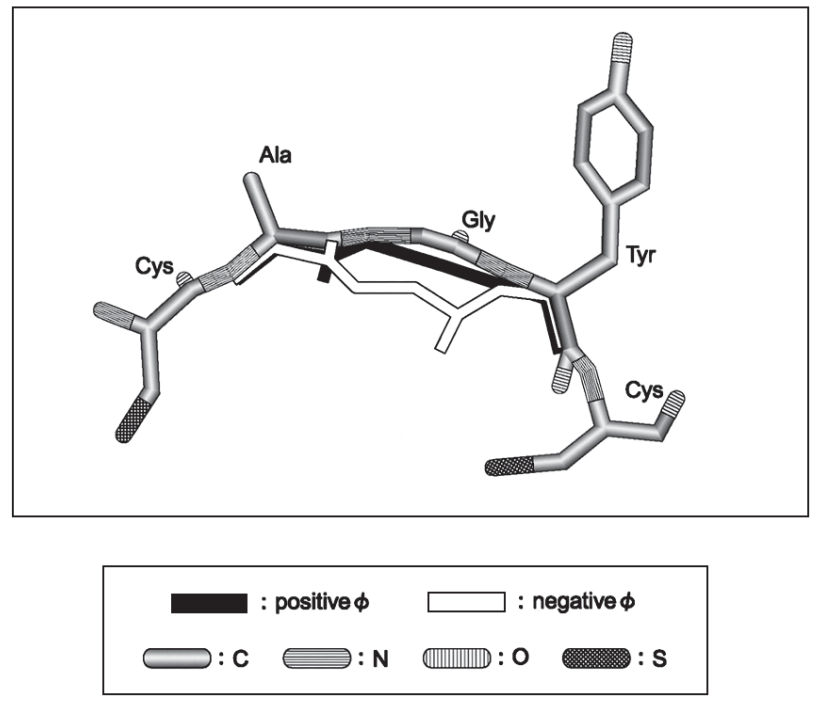

Fig. 2. Stick models of the peptide chains of CMGCC motif in the $\alpha$-chain (a) and the CAGYC motif in the $\beta$-chain (b) for the crystal structure. The stick models in black and white are computer generated averaged models and correspond to the conformations with the middle Gly having positive and negative $\Phi$ values, respectively.

demonstrated as shown in Fig. 2 (b). Ramachandran plot analysis showed that a part of the areas for $\mathrm{X}_{3}$ in the $C_{1} A_{2} X_{3}\left(G_{3}\right) Y_{4} C_{5}$ motif was located in the allowed areas for amino acids other than Gly. Then we generated a $\mathrm{C}_{\beta}$ atom at $\mathrm{X}_{3}$ in the $\mathrm{C}_{1} \mathrm{~A}_{2} \mathrm{G}_{3} \mathrm{Y}_{4} \mathrm{C}_{5}$ motif. As shown in Fig. 3, this atom is in a position to collide with two Cys residues in the $\beta$-chain ( $\beta$ Cys-9 and $\beta$ Cys-57) which are important for cystine knot formation so that residues other than Gly and Ala would not be accommodated considering the $\mathrm{C}_{\beta}$ direction. Furthermore a mutant of $\mathrm{C}_{1} \mathrm{~A}_{2} \mathrm{~A}_{3} \mathrm{Y}_{4} \mathrm{C}_{5}$ (Ala in- 


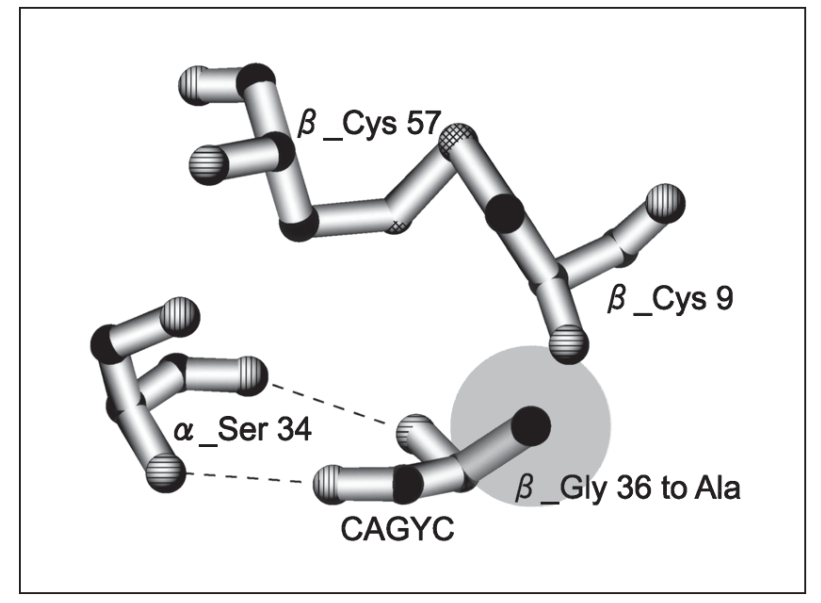

$: c \ominus: N \mathbb{O}: 0: S$

Fig. 3. A view of structures and relationships of $\mathrm{G}_{3}$ in the $\mathrm{C}_{1} \mathrm{~A}_{2} \mathrm{G}_{3} \mathrm{Y}_{4} \mathrm{C}_{5}$ region of the $\beta$-chain ( $\beta$-Gly 36 ) to Cys 9 ( $\beta$-Cys 9) and Cys 57 ( $\beta$-Cys 57) which forms a cystine knot in the $\beta$-chain, and to Ser 34 of the $\alpha$-chain $(\alpha$-Ser 34) which forms hydrogen bonds with $\beta$-Gly $36(---)$. A large gray circle shows $\mathrm{C}_{\beta}$ of Ala $36\left(\mathrm{~A}_{3}\right)$ (a mutation of the $C_{1} A_{2} X_{3}\left(A_{3}\right) Y_{4} C_{5}$ motif) which is close to the cystine knot and interferes with the hydrogen bond formation.

stead of Gly at site $\mathrm{X}_{3}$ ) could not form a heterodimer with the $\alpha$-chain because an inter molecular hydrogen bond between Gly36 in the $\mathrm{C}_{1} \mathrm{~A}_{2} \mathrm{G}_{3} \mathrm{Y}_{4} \mathrm{C}_{5}$ region of the $\beta$-chain and Ser34 of the $\alpha$-chain could not be bridged. These findings indicate that the Gly residue at site $\mathrm{X}_{3}$ $\left(G_{3}\right)$ in the $C_{1} X_{2} X_{3}\left(G_{3}\right) X_{4} C_{5}$ motif in the $\alpha$ - and $\beta$ chains is essential for heterodimer formation of glycoprotein hormones.

\section{Hypothetical disorders related to glycoprotein hormones}

Based on the previous studies, the existence of hypothetical disorders related to glycoprotein hormones is suggested as shown in Fig. 1(\{\}). Some of these disorders along with strategies and trials for their discovery are described below.

\section{1. "Congenital isolated TSH deficiency due to muta-} tion in the TRH gene" (\{a\} in Fig. 1)

The patients may have clinical features similar to congenital central hypothyroidism due to mutation in the TRH receptor gene [58] except that serum TSH and PRL may show increased responses after administration of TRH.

2. "Total glycoprotein hormone deficiency due to the mutation in common $\alpha$-subunit gene" ( $\{j\}$ in Fig. 1)

As shown in the animal model (alpha SU null mice), the common $\alpha$-subunit deficiency may induce combined TSH, LH, FSH and CG deficiency presenting congenital secondary hypothyroidism and infertility in humans. We have been looking for such a disorder but have not yet discovered any cases. However, chromosome assignment of the gene encoding the human $\alpha$ subunit showed that the gene was located on chromosome 6q [77]. Therefore, we attempted to assess pituitary thyroid functions in 5 patients with abnormalities of chromosome 6 , but these functions were within normal limits on examinations performed thus far [Miyai K, Horigome H, Kameda N, Shiraishi H and Yoshimoto $\mathrm{M}$ et al., unpublished data].

\section{3. "Congenital glycoprotein hormone deficiency due to impairment of glycosylation” ( $\{k\}$ in Fig. 1)}

Since glycosylation is known to be essential for synthesis of glycoprotein hormones, its impairment may induce loss of biological and/or immunological activities of the hormones. However, Macchia et al. [78] reported that serum total $\mathrm{T}_{4}$, free $\mathrm{T}_{4}$ index and $\mathrm{T}_{3}$ were below normal, and that TSH was in the midnormal range in patients with congenital disorders of glycosylation. A recent report by Ferrari et al. [79] also demonstrated that thyroid functions in the disorder were normal although TSH showed severe impairment of lectin binding.

\section{4. "Isolated $C G$ deficiency due to the mutation in the CG $\beta$-subunit gene" (Fig. 1)}

To date, congenital isolated deficiencies of all glycoprotein hormones except CG (TSH, LH and FSH) due to mutation in the $\beta$-subunit gene have been reported. Hypothetical patients with congenital CG deficiency may become pregnant but are not able to maintain the pregnancy (infertility). However, the patients may be diagnosed as having sterility because the pregnancy would not be detectable by common pregnant tests using the determination of CG. Recently we developed an ultra sensitive ELISA for CG which can detect a 
very low concentration of basal CG in the blood of non pregnant women. As a preliminary experiment, we determined circulating CG in 3 women with sterility of unknown etiology, but the basal CG level was detected and this level increased after administration of $\mathrm{GnRH}$, indicating that these women did not have CG deficiency [Miyai K et al., unpublished data].

\section{5. "CXGXC motif disorders"}

As described above, the $\mathrm{C}_{1} \mathrm{X}_{2} \mathrm{G}_{3} \mathrm{X}_{4} \mathrm{C}_{5}$ motif is present in all human glycoprotein hormones $\left(\mathrm{C}_{1} \mathrm{M}_{2} \mathrm{G}_{3} \mathrm{C}_{4} \mathrm{C}_{5}\right.$ in $\alpha$-subunits and $\mathrm{C}_{1} \mathrm{~A}_{2} \mathrm{G}_{3} \mathrm{Y}_{4} \mathrm{C}_{5}$ in $\beta$-subunits) where the Cys residues at both ends $\left(\mathrm{C}_{1}\right.$ and $\left.\mathrm{C}_{5}\right)$ and the middle Gly $\left(\mathrm{G}_{3}\right)$ are essential for exhibiting their hormone activities. A novel glycoprotein hormone, thyrostimulin, which is similar to TSH, also has the $\mathrm{C}_{1} \mathrm{X}_{2} \mathrm{G}_{3} \mathrm{X}_{4} \mathrm{C}_{5}$ motif as $\mathrm{C}_{1} \mathrm{~V}_{2} \mathrm{G}_{3} \mathrm{H}_{4} \mathrm{C}_{5}$ in $\alpha_{2}-(\mathrm{GPA} 2)$ and $\mathrm{C}_{1} \mathrm{~W}_{2} \mathrm{G}_{3} \mathrm{R}_{4} \mathrm{C}_{5}$ in $\beta_{5}$-(GPB5) subunits $[80,81]$.

To date, two cases of congenital glycoprotein hormone deficiency caused by mutations in the $\mathrm{C}_{1} \mathrm{X}_{2} \mathrm{G}_{3} \mathrm{X}_{4} \mathrm{C}_{5}$ motif in $\beta$-subunits have been reported; these were TSH $\left(\mathrm{C}_{1} \mathrm{~A}_{2} \mathrm{R}_{3} \mathrm{Y}_{4} \mathrm{C}_{5}\right)$ and $\mathrm{LH}\left(\mathrm{C}_{1} \mathrm{~A}_{2} \mathrm{D}_{3} \mathrm{Y}_{4} \mathrm{C}_{5}\right)$ deficiencies as described above. It seems reasonable to assume that replacements of the $\mathrm{G}_{3}, \mathrm{C}_{1}$ and $\mathrm{C}_{5}$ residues with any other residue would result in isolated deficiencies of TSH and LH as well as FSH and CG. As for the $\mathrm{C}_{1} \mathrm{M}_{2} \mathrm{G}_{3} \mathrm{C}_{4} \mathrm{C}_{5}$ motif in the $\alpha$-subunits, alteration of $\mathrm{G}_{3}, \mathrm{C}_{1}$ and $\mathrm{C}_{5}$ to any other residue may induce combined TSH, LH, FSH and CG deficiency, although such deficiencies have not yet been reported.

Furthermore, a number of similar CXGXC motifs have been found in various human proteins such as transforming growth factor- $\beta$ (CAGAC), phosphoinositide 3-kinase- $\beta$ (CAGCC), inhibin $\beta$ A chain
(CEGEC) etc. [12]. The motif $\left(\mathrm{C}_{\mathrm{k} 1} \mathrm{G}_{2} \mathrm{G}_{3} \mathrm{C}_{\mathrm{s} 4} \mathrm{C}_{\mathrm{k} 5}\right)$ in endothelial growth factor [82] is similar to that $\left(\mathrm{C}_{\mathrm{k} 1} \mathrm{M}_{2} \mathrm{G}_{3} \mathrm{C}_{\mathrm{s} 4} \mathrm{C}_{\mathrm{k} 5}\right)$ in $\alpha$-subunits of glycoprotein hormones. It would have been interesting to assume that any mutations in the motifs in these proteins could result in a loss of biological activities and induce unknown disorders.

Finally I would like to conclude this review with some of my favorite words.

"The discovery of a new disease is possible not only by accidental but also by creative powers that render these inevitable."

"Measure what is measurable and make measurable what is not so." (Galileo Galilei)

"An ounce of prevention has always been better than a pound of cure." (E. B. Michel)

"Nor is there any better way to advance the proper practice of medicine than to give our minds to the discovery of the usual law of nature, by the careful investigation of cases of rarer forms of disease." (William Harvey)

\section{Acknowledgments}

I wish to thank Drs. M. Azukizawa, Y. Hayashizaki, K. Tatsumi, K. Ishibashi, M. Kusunoki and all co-workers for their collaborative efforts, Drs. Y. Kumahara (late), N. Amino, O. Tanizawa, T. Oura and colleagues in the Department of Laboratory Medicine, Osaka University Medical School for their encouragement and helpful suggestions, the Eiken Chemical Co., Osaka Kessei Laboratories and other firms for their technical and/or financial supports.

\section{References}

1. Pierce JP, Parsons TF (1981) Glycoprotein hormones: Structure and function. Annu Rev Biochem 50: 465495.

2. Ryan RJ, Keutmann HT, Charlesworth MC, McCormick DJ, Milius RP, Calvo FO, Vutyavanich T (1987) Structure-function relationships of gonadotropins. Recent Prog Horm Res 43: 383-429.

3. Miyai K, Azukizawa M, Kumahara Y (1971) Familial isolated thyrotoropin deficiency with cretinism. $N$ Engl J Med 285: 1043-1048.

4. Hayashizaki Y, Miyai K, Kato K, Matsubara K (1985)
Molecular cloning of human thyrotropin- $\beta$ subunit gene. FEBS Lett 188: 394-400.

5. Tatsumi K, Hayashizaki Y, Hiraoka Y, Miyai K, Matsubara K (1988) The structure of the human thyrotropin $\beta$-subunit gene. Gene 73: 489-497.

6. Hayashizaki Y, Hiraoka Y, Endo Y, Miyai K, Matsubara K (1989) Thyroid-stimulating hormone (TSH) deficiency caused by a single base substitution in the CAGYC region of the $\beta$ subunit. EMBO $J$ 8: 2291-2296 (corrigenda p. 3542).

7. Hayashizaki Y, Hiraoka Y, Tatsumi K, Hashimoto T, 
Furuyama J, Miyai K, Nishijo K, Matsuura M, Kohno H, Labbe A, Matsubara K (1990) Deoxyribonucleic acid analyses of five families with familial inherited thyroid stimulating hormone deficiency. J Clin Endocrinol Metab 71: 792-796.

8. Azuma C, Miyai K, Saji F, Kamiura S, Tokugawa Y, Kimura T, Ohashi K, Koyama M, Iijima Y, Kashiwai T, Hayashizaki Y, Tanizawa O (1990) Site-specific mutagenesis of human chorionic gonadotropin (hCG)$\beta$ subunit: influence of mutation on hCG production. $J$ Mol Endocrinol 5: 97-102.

9. Kikuchi T, Koyama M, Miyai K, Kimura T, Nishikiori N, Kimura T, Azuma C, Kusunoki M, Saji F, Tanizawa O (1994) Loss of biological activity of human chorionic gonadotropin (hCG) by the amino acid substitution on "CMGCC" region of $\alpha$ subunit. Mol Cell Endocrinol 102: 1-7.

10. Miyai K, Kumazawa I, Saji F, Azuma C, Koyama M, Kimura T, Narizuka Y, Kusunoki M, Murata Y (1998) Effect of directed mutagenesis in the CMGCC region of the $\alpha$-subunit on immunoreactive human thyrotropin. Endocr J 45: 467-473.

11. Miyai K, Tatsumi K, Kusunoki M, Ashida N (1993) Congenital deficiency of thyrotropin. In: Mornex R, Jaffiol C, Leclere J (eds) Progress in Endocrinology. Parthenon Publishing Group, Carnforth UK, 313-317.

12. Kinoshita K, Kusunoki M, Miyai K (2006) Analysis of the three dimensional structure of the CXGXC motif in the $\mathrm{CMGCC}$ and $\mathrm{CAGYC}$ regions of $\alpha$ - and $\beta$-subunits of human chorionic gonadotropin: Importance of glycine residue $(\mathrm{G})$ in the motif. Endocr $J$ 53: 51-58.

13. Tatsumi K, Notomi T, Amino N, Miyai K (1992) Nucleotide sequence of complementary DNA for human Pit-1 / GHF-1. Biochim Biophy Acta 1129: 231-234.

14. Tatsumi K, Miyai K, Notomi T, Kaibe K, Amino N, Mizuno Y, Kohno H (1992) Cretinism with combined hormone deficiency caused by a mutation in the PIT1 gene. Nat Genet 1: 56-58.

15. Miyai K, Miyagi T, Ashida N, Narizuka Y, Taniguchi K, Tatsumi H, Inaoka K, Ida S, Oura T (1998) Evaluation of highly sensitive thyrotropin assay for detecting thyroid diseases in neonatal screening - preliminary studies. Endocr J 45: 761-766.

16. Turner RW, Takamura T (1962) Pseudohypoparathyroidism and hypothyroidism. Ann Intern Med 56: 276281.

17. Miyai K (1985) Hypothyroidism. Defect in hypothalamic-pituitary function. In: Delange F, Fisher DA, Malvaux P (eds) Pediatric Thyroidology. Medical and Science Publishing, Basel, Pediat Adolesc Endocr vol 14: 143-153.

18. Miyai K, Endo Y, Iijima Y, Kabutomori O, Hayashizaki Y (1988) Serum free thyrotropin $\alpha$-subunit in congenital isolated thyrotropin deficiency. Endocrinol Jpn 35: 517-521.
19. Miyai K, Azukizawa M, Onishi T, Hashimoto T, Sawazaki N, Nishi K, Kumahara Y.: Familial isolated thyrotropin deficiency (1976) In: James VHT (ed) Endocrinology. Excerpta Medica, Amsterdam, New York, Oxford, vol 12: 345-349.

20. Hayashizaki Y, Miyai K, Onishi T, Kumahara Y (1986) Effect of corticotrophin releasing factor and growth hormone releasing factor on pituitary hormone secretion in patients with congenital thyrotropin deficiency - Abnormal response of growth hormone to corticotrophin releasing factor. Horm Metab Res 18 849-853.

21. Miyai K, Hayashizaki Y, Hiraoka Y, Tatsumi K, Matsubara K, Endo Y, Nishijo K, Matsuura M, Kohno H, Labbe A (1988) Familial hypothyroidism due to thyrotropin gene abnormality. In: Imura H, Shizume K, Yoshida S (eds) Progress in Endocrinology. Excerpta Medica, Amsterdam-New York-Oxford, 545-550.

22. Mori R, Sawai T, Kinoshita E, Baba T, Matsumoto T, Yoshimoto M, Tsuji Y, Satake Y, Sawada K (1991) Rapid detection of a point mutation in thyroidstimulating hormone $\beta$-subunit gene causing congenital isolated thyroid-stimulating hormone deficiency. Japanese J Human Genetics 36: 313-316.

23. Dacou-Voutetakis C, Feltquate DM, Drakopoulou M, Kourides IA, Dracopoli NC (1990) Familial hypothyroidism caused by a nonsense mutation in the thyroid-stimulating hormone $\beta$-subunit gene. $\mathrm{Am} \mathrm{J}$ Hum Genet 46: 988-993.

24. Doeker BM, Pfaeffle RW, Pohlenz J, Andler W (1998) Congenital central hypothyroidism due to a homozygous mutation in the thyrotropin $\beta$-subunit gene follows an autosomal recessive inheritance. J Clin Endocrinol Metab 83: 1762-1765.

25. Persani L, Bonomi M, Proverbio MC, Weber G, Alberti L (2000) Congenital hypothyroidism with normal TSH level in a female carrying a novel homozygous mutation in TSH $\beta$ gene. Endocr J 47: 177 (abstract of the $12^{\text {th }}$ International Thyroid Congress, Kyoto, Japan).

26. Vuissoz JM, Deladoey J, Buyukgebiz A, Cemeroglu P, Gallati S, Mullis PE (2001) New recessive mutation in the TSH-beta subunit gene causing central isolated hypothyroidism. J Clin Endocrinol Metab 86: 4468 4471.

27. Sertedaki A, Papadimitriou A, Voutetaki A, Dracopoulou M, Maniati-Christidi M, DacouVoutetakis C (2002) Low TSH congenital hypothyroidism: identification of a novel mutation of the TSH beta-subunit gene in one sporadic case (C85R) and of mutation Q49stop in two siblings with congenital hypothyroidism. Pediatr Res 52: 935-941.

28. Pohlenz J, Dumitrescu A, Aumann U, Koch G, Melchior R, Prawitt D, Refetoff S (2002) Congenital secondary hypothyroidism caused by exon skipping due to a homozygous donor splice site mutation in the 
TSH beta-subunit gene. J Clin Endocrinol Metab 87: 336-339.

29. Morales AE, Shi JD, Wang CY, She JX, Muir A (2004) Novel TSH beta subunit gene mutation causing congenital central hypothyroidism in a newborn male. $J$ Pediatr Endocrinol Metab 17: 355-359.

30. Karges B, Leheup B, Schoenle E, Castro-Correia C, Fontoura M, Pfaffle R, Andler W, Debatin KM, Karges W (2004) Compound heterozygous and homozygous mutation of the TSH beta gene as a cause of congenital central hypothyroidism in Europe. Horm Res 62: 149155.

31. Ingraham HA, Chen RP, Mangalam HJ, Elsholtz HP, Flynn SE, Lin CR, Simmons DM, Swanson L, Rosenfeld MG (1988) A tissue-specific transcription factor containing a homeodomain specifies a pituitary phenotype. Cell 55: 519-529.

32. Bartke (1965) The response of two types of dwarf mice to growth hormone, thyrotropin, and thyroxine. Gen Comp Endocrinol 5: 418-426.

33. Li S, Crenshaw III BC, Rawson EJ, Simmons DM, Swanson LW, Rosenfeld MG (1990) Dwarf locus mutants lacking three pituitary cell types result from mutations in the POU-domain gene pit-1. Nature 347: 528-533.

34. Radovick S, Nations M, Du Y, Berg LA, Weintraub $\mathrm{BD}$, Wondisford FE (1992) A mutation in the POUhoneodomain of Pit-1 responsible for combined pituitary hormone deficiency. Science 257: 1115-1118.

35. Pfaeffle RW, DiMattia GE, Parks JS, Brown MR, Wit JM, Jansen M, Vander Nat H, Van den Brande JL, Rosenfeld MG, Ingraham HA (1992) Mutation of the POU-specific domein of Pit-1 and hypopituitarism without pituitary hypoplasia. Science 257: 1118-1121.

36. Ohta K, Nobukuni Y, Mitsubuchi H, Fujimoto S, Matsuo N, Inagaki H, Endo F, Matsuda I (1992) Mutations in the Pit-1 gene in children with combined pituitary hormone deficiency. Biochem Biophys Res Commun 189: 851-855.

37. McLennan K, Jeske Y, Cotterill A, Cowley D, Penfold J, Jones T, Howard N, Thomsett M, Choong C (2003) Combined pituitary hormone deficiency in Australian children: clinical and genetic correlates. Clin Endocrinol (Oxf) 58: 785-794.

38. Turton JP, Reynaud R, Mehta A, Torpiano J, Saveanu A, Woods KS, Tiulpakov A, Zdravkovic V, Hamilton J, Attard-Montalto S, Parascandalo R, Vella C, Clayton PE, Shalet S, Barton J, Brue T, Dattani MT (2005) Novel mutations within the POU1F1 gene associated with variable combined pituitary hormone deficiency. $J$ Clin Endocrinol Metab 90: 4762-4770.

39. Wu W, Cogan JD, Pfaffle RW, Dasen JS, Frisch H, O'Connell SM, Flynn SE, Brown MR, Mullis PE, Parks JS, Phillips JA 3rd, Rosenfeld MG (1998) Mutations in PROP1 cause familial combined pituitary hormone deficiency. Nat Genet 18: 147-149.

40. Fofanova O, Takamura N, Kinoshita E, Parks JS, Brown MR, Peterkova VA, Evgrafov OV, Goncharov NP, Bulatov AA, Dedov II, Yamashita S (1998) Compound heterozygous deletion of the PROP-1 gene in children with combined pituitary hormone deficiency. J Clin Endocrinol Metab 83: 2601-2604.

41. Paracchini R, Giordano M, Corrias A, Mellone S, Matarazzo P, Bellone J, Momigliano-Richiardi P, Bona G (2003) Two new PROP1 gene mutations responsible for compound pituitary hormone deficiency. Clin Genet 64: 142-147.

42. Tatsumi KI, Kikuchi K, Tsumura K, Amino N (2004) A novel PROP1 gene mutation (157delA) in Japanese siblings with combined anterior pituitary hormone deficiency. Clin Endocrinol (Oxf) 61: 635-640.

43. Reynaud R, Barlier A, Vallette-Kasic S, Saveanu A, Guillet MP, Simonin G, Enjalbert A, Valensi P, Brue T (2005) An uncommon phenotype with familial central hypogonadism caused by a novel PROP1 gene mutant truncated in the transactivation domain. J Clin Endocrinol Metab 90: 4880-4887.

44. Nose O, Tatsumi K, Nakano Y, Amino N (2006) Congenital combined pituitary hormone deficiency attributable to a novel PROP1 mutation (467insT). $J$ Pediatr Endocrinol Metab 19: 491-498.

45. Dattani MT, Martinez-Barbera JP, Thomas PQ, Brickman JM, Gupta R, Martensson IL, Toresson H, Fox M, Wales JK, Hindmarsh PC, Krauss S, Beddington RS, Robinson IC (1998) Mutations in the homeobox gene HESX1/Hesx1 associated with septo-optic dysplasia in human and mouse. Nat Genet 19: 125-133.

46. Tajima T, Hattorri T, Nakajima T, Okuhara K, Sato K, Abe S, Nakae J, Fujieda K (2003) Sporadic heterozygous frameshift mutation of HESX1 causing pituitary and optic nerve hypoplasia and combined pituitary hormone deficiency in a Japanese patient. J Clin Endocrinol Metab 88: 45-50.

47. Carvalho LR, Woods KS, Mendonca BB, Marcal N, Zamparini AL, Stifani S, Brickman JM, Arnhold IJ, Dattani MT (2003) A homozygous mutation in HESX1 is associated with evolving hypopituitarism due to impaired repressor-corepressor interaction. J Clin Invest 112: 1192-1201.

48. Cohen RN, Cohen LE, Botero D, Yu C, Sagar A, Jurkiewicz M, Radovick S (2003) Enhanced repression by HESX1 as a cause of hypopituitarism and septooptic dysplasia. J Clin Endocrinol Metab 88: 4832-4839.

49. Netchine I, Sobrier ML, Krude H, Schnabel D, Maghnie M, Marcos E, Duriez B, Cacheux V, Moers A, Goossens M, Gruters A, Amselem S (2000) Mutations in LHX3 result in a new syndrome revealed by combined pituitary hormone deficiency. Nat Genet 25 : $182-186$.

50. Bhangoo AP, Hunter CS, Savage JJ, Anhalt H, 
Pavlakis S, Walvoord EC, Ten S, Rhodes SJ (2006) Clinical case seminar: a novel LHX3 mutation presenting as combined pituitary hormonal deficiency. J Clin Endocrinol Metab 91: 747-753.

51. Machinis K, Pantel J, Netchine I, Leger J, Camand OJ, Sobrier ML, Dastot-Le Moal F, Duquesnoy P, Abitbol M, Czernichow P, Amselem S (2001) Syndromic short stature in patients with a germline mutation in the LIM homeobox LHX4. Am J Hum Genet 69: 961-968.

52. Woods KS, Cundall M, Turton J, Rizotti K, Mehta A, Palmer R, Wong J, Chong WK, Al-Zyoud M, El-Ali M, Otonkoski T, Martinez-Barbera JP, Thomas PQ, Robinson IC, Lovell-Badge R, Woodward KJ, Dattani MT (2005) Over- and underdosage of SOX3 is associated with infundibular hypoplasia and hypopituitarism. Am J Hum Genet 76: 833-849.

53. Illig R, Krawezynska, H, Torressani T (1975) Elevated plasma TSH and hypothyroidism in children with hypothalamic hypopituitarism. J Clin Endocrinol Metab 41: 722-728.

54. Faglia G, Bitensky L, Pinchera A, Ferrari C, Paracchi A, Beck-Peccoz P, Ambrosi B, Spada A (1979) Thyrotropin secretion in patients with central hypothyroidism: evidence for reduced biological activity of immunoreactive thyrotropin. J Clin Endocrinol Metab 48: 989-998.

55. Spitz IM, Le Roith D, Hirsch H, Carayon P, Pekonen F, Liel Y, Sobel R, Chorer Z, Weintraub B (1981) Increased high-molecular-weight thyrotropin with impaired biologic activity in a euthyroid man. $N$ Engl $J$ Med 304: 278-282.

56. Smail PJ, Isles TE, Ackroyd RS (1979) A boy with low-TSH hypothyroidism. Arch Dis Child 54: 475477.

57. Niimi H, Inomata H, Sasaki N, Nakajima H (1982) Congenital isolated thyrotrophin releasing hormone deficiency. Arch Dis Child 57: 877-878.

58. Collu R, Tang J, Castagne J, Lagace G, Masson N, Huot C, Deal C, Delvin E, Faccenda E, Eidne KA, Van Vliet G (1997) A novel mechanism for isolated central hypothyroidism: inactivating mutations in the thyrotropin-releasing hormone receptor gene. J Clin Endocrinol Metab 82: 1561-1565.

59. Dussault JH, Coulombe P, Laberge C, Letarte J, Guyda H, Khoury K (1975) Preliminary report on a mass screening program for neonatal hypothyroidism. $J$ Pediatr 86: 670-674.

60. Miyai K, Ishibashi K, Kawashima M (1980) Enzyme immunoassay of thyroxine in serum and dried blood samples on filter paper. Endocrinol Jpn 27: 375-380.

61. Mizuta H, Miyai K, Ichihara K, Amino N, Harada T, Nose O, Tanizawa O (1982) Radioimmunoassay of "free thyroxine" in dried blood spots on filter paper preliminary observations on the effective differentiation of subjects with congenital hypothyroidism from those with subnormal thyroxin-binding globulin and normal subjects. Clin Chem 28: 505-508.

62. Hata N, Miyai K, Ito M, Endo Y, Iijimi Y, Mizuta H, Amino N, Nose O, Harada T (1985) Enzyme immunoassay of free thyroxine in dried blood samples on filter paper. Clin Chem 31: 750-753.

63. Foley TP Jr, Klein AH, Agustin AV (1975) Screening for congenital hypothyroidism by the determination of thyrotropin level. In: Fisher DA, Burrow GN (eds) Perinatal Thyroid Physiology and Disease. Raven Press, New York, 255-261.

64. Irie M, Enomoto K, Naruse H (1975) Measurement of thyroid-stimulating hormone in dried blood spot. Lancet 2: 1233-1234.

65. Miyai K, Oura T (1976) Thyrotrpin determination as a screening test for neonatal hypothyroidism. $N$ Engl $J$ Med 294: 904

66. Miyai K, Nishi K, Kawashima M, Oura T, Tsuruhara T (1976) An improved assay of thyrotropin in dried blood samples on filter paper. Clin Chim Acta 73: 241249.

67. Miyai K, Ishibashi K, Kumahara Y (1976) Enzymelinked immunoassay of thyrotropin. Clin Chim Acta 67: 263-268.

68. Kato N, Ishii S, Naruse H, Irie M, Arakawa H (1980) Enzyme immunoassay of thyroid-stimulating hormone using dried blood samples. A simple technique of screening for congenital hypothyroidism. Analyt Lett 13: $1555-1565$.

69. Miyai K, Ishibashi K, Kawashima M (1981) Two-site immunoenzymometric assay for thyrotropin in dried blood samples on filter paper. Clin Chem 27: 14211423.

70. van Tijn DA, de Vijlder JJ, Verbeeten B Jr, Verkerk PH, Vulsma T (2005) Neonatal detection of congenital hypothyroidism of central origin. J Clin Endocrinol Metab 90: 3797-3799.

71. Miyai K, Inaoka K, Miyagi T, Committee for Newborn and Infant Screening in Osaka (CONISO) (2005) Further studies on occurrence of congenital dysgenetic hypothyroidism in Osaka, Japan. Endocr $J$ 52: 599 603.

72. Valdes-Socin H, Salvi R, Daly AF, Gaillard RC, Quatresooz P, Tebeu PM, Pralong FP, Beckers A (2004) Hypogonadism in a patient with a mutation in the luteinizing hormone beta-subunit gene. $N$ Engl $J$ Med 351: 2619-2625.

73. Wheeler DL, Barrett $\mathrm{T}$, Benson DA, Bryant SH, Canese K, Chetvernin V, Church DM, DiCuccio M, Edgar R, Federhen S, Geer LY, Helmberg W, Kapustin Y, Kenton DL, Khovayko O, Lipman DJ, Madden TL, Maglott DR, Ostell J, Pruitt KD, Schuler GD, Schriml LM, Sequeira E, Sherry ST, Sirotkin K, Souvorov A, Starchenko G, Suzek TO, Tatusov R, Tatusova TA, Wagner L, Yaschenko E (2006) Database resources of 
the National Center for Biotechnology Information. Nucleic Acids Res 34 (Database issue): D173-180.

74. Hayashi H, Hayashi T, Hanaoka Y (1992) Amphibian lutropin and follitropin from the bullfrog Rana catesbeiana. Complete amino acid sequence of the alpha subunit. Eur J Biochem 203: 185-191.

75. Lapthorn AJ, Harris DC, Littlejohn A, Lustbader JW, Canfield RE, Machin KJ, Morgan FJ, Isaacs NW (1994) Crystal structure of human chorionic gonadotropin. Nature 369: 455-461.

76. Wu H, Lustbader JW, Liu Y, Canfield RE, Hendrickson WA (1994) Structure of human chorionic gonadotropin at 2.6 A resolution from MAD analysis of the selenomethionyl protein. Structure 2: 545-548.

77. Naylor SL, Chin WW, Goodman HM, Lalley PA, Grzeschik KH, Sakaguchi AY (1983) Chromosome assignment of genes encoding the alpha and beta subunits of glycoprotein hormones in man and mouse. Somatic Cell Genet 9: 757-770.

78. Macchia PE, Harrison HH, Scherberg NH, Sunthornthepfvarakul T, Jaeken J, Refetoff S (1995) Thyroid function tests and characterization of thyroxine- binding globulin in the carbohydrate-deficient glycoprotein syndrome type I. J Clin Endocrinol Metab 80: 3744-3749.

79. Ferrari MC, Parini R, Di Rocco MD, Radetti G, BeckPeccoz P, Persani L (2001) Lectin analyses of glycoprotein hormones in patients with congenital disorders of glycosylation. Eur J Endocrinol 144: 409-416.

80. Hsu SY, Nakabayashi K, Bhalla A (2002) Evolution of glycoprotein hormone subunit genes in bilateral metazoa: identification of two novel human glycoprotein hormone subunit family genes, GPA2 and GPB5. Mol Endocrinol 16: 1538-1551.

81. Nakabayashi K, Matsumi H, Bhalla A, Bae J, Mosselman S, Hsu SY, Hsueh AJ (2002) Thyrostimulin, a heterodimer of two new human glycoprotein hormone subunits, activates the thyroid-stimulating hormone receptor. J Clin Invest 109: 1445-1452.

82. Muller YA, Heiring C, Misselwitz R, Welfle K, Welfle $H$ (2002) The cystine knot promotes folding and not thermodynamic stability in vascular endothelial growth factor. J Biol Chem 277: 43410-43416. 